\title{
IMPROVED DIAGNOSIS OF CENTRAL NERVOUS SYSTEM TUBERCULOSIS BY MPB64-TARGET PCR
}

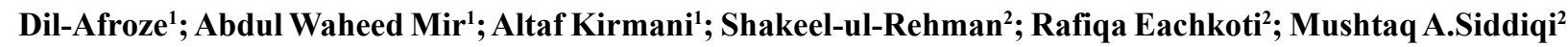 \\ Departments of Immunology \& Molecular Medicine², Neurosurgery ${ }^{1}$, Sher-I-Kashmir Institute of Medical Sciences, Soura, \\ India.
}

Submitted: March 20, 2007; Returned to authors for corrections: September 22, 2007; Approved: April 25, 2008.

\begin{abstract}
Central nervous system (CNS) tuberculosis is a serious clinical problem, the treatment of which is sometimes hampered by delayed diagnosis. Clearly, prompt laboratory diagnosis is of vital importance as the spectrum of disease is wide and abnormalities of the cerebrospinal fluid (CSF) are incredibly variable. Since delayed hypersensitivity is the underlying immune response, bacterial load is very low. The conventional bacteriological methods rarely detect Mycobacterium tuberculosis in CSF and are of limited use in diagnosis of tuberculous meningitis (TBM). This double blind study was, therefore, directed to the molecular analysis of CNS tuberculosis by an in-house-developed PCR targeted for amplification of a 240bp nucleotide sequence coding for MPB64 protein specific for Mycobacterium tuberculosis. Based on the clinical criteria, 47 patients with CNS tuberculosis and a control group of 10 patients having non-tubercular lesions of the CNS were included in the study. Analyses were done in three groups; one group consisting of 27 patients of TBM, a second group of 20 patients with intracranial tuberculomas and a third group of 10 patients having nontubercular lesions of the CNS acted as control. There were no false positive results by PCR and the specificity worked out to be $100 \%$. In the three study groups, routine CSF analysis (cells and chemistry), CSF for AFB smear and culture were negative in all cases. PCR was positive for $21 / 27$ patients ( $77.7 \%$ sensitivity) of the first group of TBM patients, $6 / 20$ patients ( $30 \%$ sensitivity) of the second group with intracranial tuberculomas were positive by PCR and none was PCR-positive (100\% specificity) in the third group. Thus, PCR was found to be more sensitive than any other conventional method in the diagnosis of clinically suspected tubercular meningitis.
\end{abstract}

Key-words: CNS tuberculosis, tuberculous meningitis (TBM), intracranial tuberculomas, PCR, Mycobacterium tuberculosis.

\section{INTRODUCTION}

Tuberculosis (TB) is a major global problem and a public health issue of considerable magnitude. Approximately, eight million new cases of TB and three million deaths are reported annually (3). In recent times, there has been a resurgence of tuberculosis in both developing and developed countries; the incidence varies from 9 cases per 100,000 persons per year in the US to $110-165$ cases per 100,000 persons in the developing countries of Asia and Africa $(7,20,24)$. The attributing risk factors include the increasing prevalence of HIV infection, overcrowding in the urban population and in abnormal communities (such as prisons, concentration camps and refugee colonies), poor nutritional status, appearance of drug-resistant strains of tuberculosis and ineffective tuberculosis control programmes.

TB is a chronic, systemic infectious disease caused by the Mycobacterium tuberculosis primarily manifesting as pulmonary Koch's. The inhaled bacilli can localize in alternate sites, leading to extrapulmonary TB (EPTB). Tuberculous involvement of the central nervous system (CNS) is an important and serious type

*Corresponding Author. Mailing address: Department of Immunology \& Molecular Medicine, Sher-I-Kashmir Institute of Medical Sciences, Soura, J\&K-190011 India. Phone No.+91-194-2401013 Ext. 2262 Fax No.+91-194-2403470. E-mail: siddiqimushtaq@yahoo.co.in 
of extra-pulmonary involvement (26). It has been estimated that approximately $10 \%$ of all patients with tuberculosis have CNS involvement (27). Fatality rates in developing countries have been reported to range from 44 to $69 \%(6,8,19)$. In fact, missed diagnosis and delayed treatment often results in serious longterm debilitating complications. Moreover, the clinical response to antituberculosis therapy in all forms of neuro-TB is excellent, provided the diagnosis is made early; before an irreversible neurological defect occurs (delay in diagnosis is directly related to neurologic sequelae in $20-25 \%$ of patients who do not receive early treatment). Clearly, prompt laboratory diagnosis is of vital importance. The great majority of patients with neuro-TB are diagnosed on the basis of clinical criteria, radiographic findings and laboratory investigation of the cerebrospinal fluid (CSF) (11). Acid-fast staining of CSF sediment is the most rapid method for detection of mycobacteria, but this method requires $>10^{4}$ cells $\mathrm{ml}^{-1}$ hence lacks sensitivity. Conventional methods like microscopy and culture, although considered as gold standards, are quite inadequate (12). The diagnostic reference standard, isolation of Mycobacterium tuberculosis from CSF samples, is insufficiently timely (it requires 2-6 weeks) to aid clinical judgment with respect to treatment and because of the paucibacillary state in the cerebrospinal fluid this method is insensitive if large amounts of CSF are not tested. PCR and molecular analysis techniques show promise as tools for rapid diagnosis of pulmonary, EPTB and CNS tuberculosis $(1,3,11,12,17,18,23)$. However, the accuracy and reproducibility of these molecular analysis techniques for the detection of M. tuberculosis in CSF has not been clearly defined. Therefore, an in-house developed, MPB64 gene targeted PCR was evaluated at our centre for rapid and specific diagnosis of CNS tuberculosis.

\section{MATERIALAND METHODS}

The subjects comprised patients and controls admitted in the tertiary care referral centre in the department of Neurosurgery Sher-i-Kashmir Institute of Medical Sciences, Srinagar, Kashmir, India, between January 2003 and January 2005. The patients presented history, clinical features and CT scan/MRI strongly suggestive of tubercular lesions of the Central Nervous System (CNS). The patients with the presumptive diagnosis of tuberculomas without neuro-deficit were treated on out-patient basis and those with TBM and tuberculomas with neuro-deficit were hospitalized.

Based on the clinical criteria, 47 patients with CNS tuberculosis and a control group of 10 patients having nontubercular lesions of the CNS were included in the study. Patients were divided in three groups: Category I: 27 patients diagnosed of tuberculous meningitis (TBM) based on clinical features of fever, persistent headache, neck stiffness, vomiting, alteration of sensorium or a focal deficit, mental changes and confusion, lethargy and stupor for more than seven days with the suggestive radiological and CT findings including basal exudate, hydrocephalus, infarcts and gyral enlargement confirmed by various diagnostic procedures like biochemical examination of CSF showing the presence of $>10 \mathrm{WBC} / \mathrm{ml}$ and $>80 \%$ lymphocytes, protein concentration of $>40 \mathrm{mg} / \mathrm{dl}$ and sugar concentration less than $60 \%$ of corresponding blood glucose; Category II: 20 patients with intracranial tuberculomas and Category III: 10 patients having non-tubercular lesions of the CNS (controls).

The samples were received in ice and stored at $-20^{\circ} \mathrm{C}$ until analysis. A bacteriological analysis of CSF was performed by the Ziehl-Neelsen method and culture was done on Lowenstein-Jensen slants for all samples. A double-blind study was conducted; the samples were transferred to the laboratory for PCR after coding.

PCR was performed in three different areas, physically separated from each other as a precaution to avert crosscontamination. DNA was extracted from CSF samples (23) by centrifugation at $3000 \mathrm{rpm}$ for $30 \mathrm{~min}$, followed by treating 200 $\mu \mathrm{l}$ of the sediment with equal volume of lysis buffer (consisting of $0.2 \mathrm{M} \mathrm{NaOH}, 2 \mathrm{M} \mathrm{NaCl}$ and $1 \% \mathrm{SDS}$ ) and $100 \mu \mathrm{g}$ proteinase- $\mathrm{K}$ at $60^{\circ} \mathrm{C}$ for 1 hour followed by $95^{\circ} \mathrm{C}$ for $15 \mathrm{~min}$ to inactivate proteinase $\mathrm{K}$. The lysate was extracted successively with chloroform. The aqueous phase was adjusted to $0.3 \mathrm{M}$ sodium acetate ( $\mathrm{pH}$ 5.2), precipitated with ethanol and dissolved in double distilled water.

The target for the PCR assay was MPB64 gene (24) which codes for an immunogenic protein specific to Mycobacterium tuberculosis complex. The sequences of the two primers used were:

Forward primer (460-479) 5'-TCCGCTGCCAGTCGTCTTCC-3' Reverse primer (700-681) 5'-GTCCTCGCGAGTCTAGGCCA-3'

DNA amplification by PCR was performed in the total reaction volume of $25 \mu \mathrm{l}$ with $5 \mu 1$ of extracted DNA, $10 \mathrm{mM}$ Tris-Cl $(\mathrm{pH}$ 8.3), $1.5 \mathrm{mM} \mathrm{MgCl}_{2}, 50 \mathrm{mM} \mathrm{NaCl}$, gelatin $0.01 \%$ (w/v), $100 \mu \mathrm{M}$ of each dNTP (Genei-India), $0.5 \mu \mathrm{M}$ of each primer \& 0.5 Units of Taq polymerase (Genei-India). Amplification was carried out on a programmable Minicycler ${ }^{\mathrm{TM}}$ (MJ Research, USA). Initial denaturation at $94^{\circ} \mathrm{C}$ for $5 \mathrm{~min}$. was proceeded by 30 cycles each of denaturation $\left(94^{\circ} \mathrm{C}\right.$ for $30 \mathrm{sec}$.), annealing $\left(60^{\circ} \mathrm{C}\right.$ for 1 $\mathrm{min})$ and extension $\left(72^{\circ} \mathrm{C}\right.$ for $\left.2 \mathrm{~min}\right)$ followed by a final extension at $72^{\circ} \mathrm{C}$ for $7 \mathrm{~min}$.

The amplified product was electrophoresed into $2 \%$ agarose gels. The gels were stained with ethidium bromide and visualized in a UV-transilluminator (Vilber Lourmat, France). The presence of a $240 \mathrm{bp}$ fragment indicated a positive test (Fig. 1).

\section{RESULTS AND DISCUSSION}

In this retrospective study, overall 57 patients were analyzed by an in-house developed, MPB64 gene targeted PCR to evaluate its diagnostic efficacy for rapid and specific diagnosis 


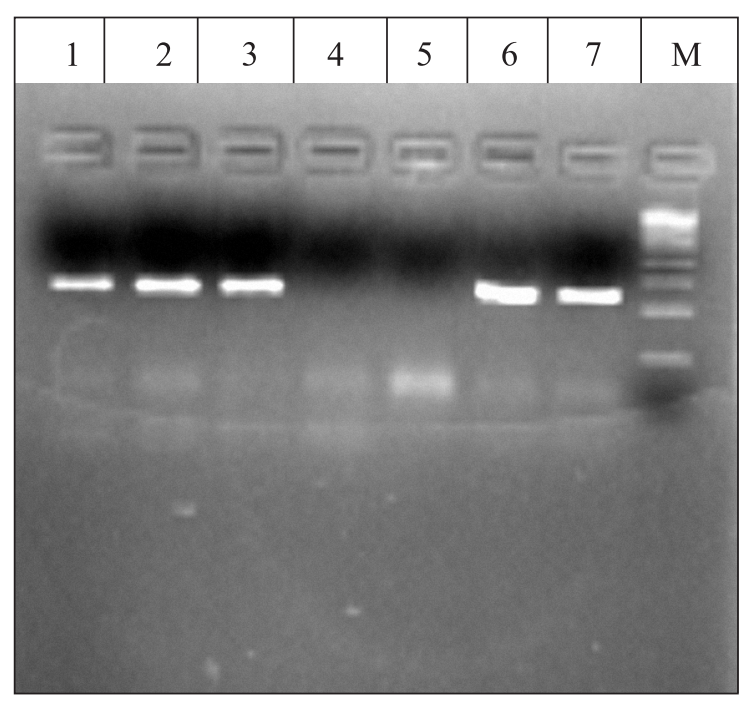

Figure 1. MPB64 gene-targeted PCR for detection of Mycobacterium tuberculosis. Electrophoretic separation of the amplicon into 2\% agarose gel is documented across Lanes 1-7. Lanes 1-3 represent the clinical cerebrospinal fluid samples, Lanes 4 and 5 exemplify the colony-PCR from atypical Mycobacterium (Mycobacterium bovis) as negative control and lanes 6 and 7 stand for the colony-PCR from Mycobacterium tuberculosis culture of the clinical samples (other than CSF) as positive control. The presence of a $240 \mathrm{bp}$. amplicon in the Lanes 1, 2, 3, 6 and 7 indicated the presence of the target.

of CNS tuberculosis. Based on the clinical criteria, 47 patients with CNS tuberculosis and a control group of 10 patients having non-tubercular lesions of the CNS included in the study were analyzed for CNS tuberculosis. Microscopic examination by ZN-staining indicated absence of AFB in all CSF samples (Table 1). The detection limit of microscopy is $10^{4}$ mycobacteria per milliliter whereas in view of the fact that delayed hypersensitivity is the underlying immune response in CNS-TB, the paucibacillary state could be accounted for these negative results. These results are comparable to those reported in literature of only $0 \%$ to $10 \%$ of Ziehl Neelsen positive results $(5,9,11,13)$ in TBM patients. CSF for AFB culture was also negative in all cases. The chance of growing mycobacteria becomes higher with the increase of sample volume. Only 2-3 $\mathrm{ml}$ of CSF per patients were available, and part of this volume, had to be utilized for ZN-staining and PCR, Thus negative culture results in all the patients with CNS-TB could be attributed to sampling difficulties.

Mycobacterium tuberculosis specific MPB64 targeted sequence was detected (Fig. 1) in CSF samples from 21 out of 27 patients of the first group of TBM patients of Category I, whose microscopy and culture results were negative (Table 1). Out of 20 cases of Category II, CSF analyses for AFB smear and culture
Table 1. Evaluation of various diagnostic methods for CNS-TB diagnosis.

\begin{tabular}{lccccc}
\hline Patient & \multirow{2}{*}{$\begin{array}{c}\text { Number } \\
\text { category }\end{array}$} & \multicolumn{4}{c}{ Positive by } \\
\cline { 3 - 6 } & & AFB & Culture & HPE & PCR \\
\hline $\begin{array}{l}\text { category I } \\
\text { (TBM) }\end{array}$ & 27 & none & none & 3 & 21 \\
$\begin{array}{l}\text { category II } \\
\text { (Intracranial } \\
\text { tuberculomas) } \\
\text { category III } \\
\text { (Control) }\end{array}$ & 20 & none & none & 2 & 6 \\
\hline
\end{tabular}

$\mathrm{AFB}=$ Acid Fast Bacilli; HPE $=$ Histo-pathological examination; $\mathrm{PCR}$ $=$ Polymerase chain reaction; $\mathrm{TBM}=$ Tuberculous Meningitis.

were negative while PCR was positive for six patients only, while remaining cases were negative. There were no false positive results by PCR (out of 10 control cases none tested positive for PCR) and the specificity worked out to be $100 \%$ (Table 2). The sensitivity of the in-house developed MPB64 targeted PCR as a diagnostic tool to detect CNS-TB worked out to be $77.7 \%$ for TBM and $30 \%$ for intracranial tuberculomas.

Among the 47 cases considered either definitely TBM or intracranial tuberculoma, on the basis of clinical and laboratory findings, PCR proved to be a more sensitive method, detecting 21 out of 27 of TBM cases (77.7\%), 6 out of 20 patients of intracranial tuberculmas (30\%) whereas none were positive either by culture or AFB staining and only $10-11 \%$ of the CNS-TB cases could be picked up on histopathological examination of the biopsy samples (Table 2). Some studies report a relatively higher sensitivity of PCR for the diagnosis of TBM, ranging from $75-90 \%$, but some authors had tested very small number of patients (22) or had used a selected patient group (21) or had a considerable number of false positives (16). An explanation for the lower sensitivity of PCR in our study could be attributed to the small volume of CSF (mean volume 200 - $300 \mu \mathrm{l}$ ) available for testing (after using for smear and culture) so that the sample could not be concentrated. The volume of sample is of great significance in PCR, especially in CNS-TB, due to frequent low number of bacteria in the CSF. Culture of CSF also requires larger volume and when both culture and PCR have to be done, the minimum volume of CSF should be $2 \mathrm{ml}$. Another reason for low sensitivity of PCR may be presence of PCR inhibitors in the CSF as well as poor lysis of mycobacteria (15). False negatives have occurred in two studies, in which the reported PCR sensitivities $(17,22)$ were $32 \%$ and $85 \%$. These results suggest that the PCR is more sensitive than other co-existing conventional methods, but still not absolute to identify all cases of CNS-TB. 
Table 2. Sensitivity and specificity of the methods for diagnosis of CNS-TB.

\begin{tabular}{|c|c|c|c|c|c|c|c|}
\hline \multirow{2}{*}{$\begin{array}{l}\text { Diagnostic } \\
\text { method }\end{array}$} & \multirow{2}{*}{$\begin{array}{l}\text { Number of positive } \\
\text { CSF samples }\end{array}$} & \multicolumn{3}{|c|}{ TBM } & \multicolumn{3}{|c|}{ Intracranial tuberculoma } \\
\hline & & Positive & Sensitivity & Specificity & Positive & Sensitivity & Specificity \\
\hline culture & none & none & $0 \%$ & $0 \%$ & none & $0 \%$ & $0 \%$ \\
\hline HPE & 5 & 3 & $11 \%$ & $100 \%$ & 2 & $10 \%$ & $100 \%$ \\
\hline PCR & 27 & 21 & $77.7 \%$ & $100 \%$ & 6 & $30 \%$ & $100 \%$ \\
\hline
\end{tabular}

$\mathrm{AFB}=$ Acid Fast Bacilli; HPE $=$ Histo-pathological examination $; \mathrm{PCR}=$ Polymerase chain reaction; $\mathrm{TBM}=$ Tuberculous Meningitis CSF $=$ Cerebro-spinal fluid.

This study is the first of its kind from the Kashmir valley in north India with such large number of samples to support the credence that PCR deserves a place in the laboratory diagnosis of central nervous system tuberculosis but careful adherence to the test protocol is mandatory. Importantly, majority of patients with tubercular meningitis and intracranial tuberculomas can be managed non-operatively. Results of PCR are available with speed comparable to microscopy; sensitivity is higher than both microscopy and culture and the direct identification of the organism, as belonging to the M.tuberculosis complex is possible. To further enhance the sensitivity of PCR, alternative procedures like double repetitive-element PCR (DRE-PCR) using hot-Taq should be employed (2). However, over-reliance on PCR should be avoided, as premature cessation of treatment will have serious consequence in patients with TBM, in whom PCR is negative. Hence, a combination of clinical criteria and PCR is needed for the final outcome to address the disease.

\section{RESUMO}

\section{Diagnóstico da tuberculose do sistema nervoso central por MPB64-Target PCR}

A tuberculose do sistema nervoso central (CNS) é um problema clínico sério, cujo tratamento é dificultado pelo diagnóstico tardio. O diagnóstico laboratorial rápido é de importância vital considerando que o espectro da doença é amplo e as anormalidades do liquor são muito variáveis. Considerando que a hipersensibilidade tardia é a resposta imune fundamental, a carga bacteriana é muito baixa. Os métodos bacteriológicos convencionais raramente detectam Mycobacterium tuberculosis no liquor e são de uso limitado para diagnóstico da meningite tuberculosa (TBM). O presente estudo duplo-cego objetivou a análise molecular da tuberculose do CNS através de um PCR desenvolvido in-house direcionado para a amplificação de uma seqüência de nucleotídios de 240pb que codificam a proteína MPB64 especifica de Mycobacterium tuberculosis. Baseandose em critérios clínicos, selecionou-se 47 pacientes com tuberculose do CNS e um grupo controle de 10 pacientes com lesões não-tuberculosas no CNS. As análises foram divididas em três grupos: um grupo de 27 pacientes com TBM, um segundo grupo com 20 pacientes com tuberculomas intracraniais e um terceiro grupo de 10 pacientes com lesões não-tuberculosas no CNS (controles). O PCR não forneceu nenhum resultado falsopositivo, com $100 \%$ de especificidade. Em todos os três grupos de estudo, os resultados das análises de rotina do liquor por histologia, química e baciloscopia e também cultura foram negativos em todos os casos. No primeiro grupo de pacientes com TBM, PCR foi positivo em $21 / 27$ pacientes (sensibilidade de $77,7 \%$ ). No segundo grupo de pacientes com tuberculomas intracraniais, 6/20 foram positivos (sensibilidade de 30\%). Nenhum dos pacientes do grupo controle foi positivo (100\% de especificidade). Dessa forma, o PCR mostrou-se mais sensível que os métodos convencionais no diagnóstico de casos suspeitos de meningite tuberculosa.

Palavras-chave: tuberculose do sistema nervoso central, meningite tuberculosa, tuberculomas intracraniais, PCR, Mycobacterium tuberculosis

\section{REFERENCES}

1. Bonington, A.; Strang, G.J.I.; Klapper, P.E.; Hod, S.V.; Rubombora, W.; Penny, M.; Willers, R.; Winkins, E.G.L. (1998). Use of the Roche AMPLICOR Mycobacterium tuberculosis PCR in early diagnosis of tuberculous meningitis. J. Clin. Microbiol., 36 (5), 12511254.

2. Cavalcanti, H.R.; Marques, E.; Fonseca, L.S.; Saad, M.H.F. (2007). Do DNA extraction methods and Taq polymerase quality improve the double repetitive element (DRE) PCR typing method for Mycobacterium tuberculosis strains? Braz. J. Microbiol., 38: 409412.

3. Dil-Afroze; Sharma, D.; Dhobi, G.N.; Sonaullah Shah, S.; Eachkoti, R.; Hussain, I.; Shah, Z.A.; Siddiqi, M.A. (2006). Evaluation of polymerase chain reaction for rapid diagnosis of clinically suspected tuberculous pleurisy. Ind. J. Clin. Biochem., 21 (2), 76-79.

4. Dolin, P.J.; Raviglione, M.C.; Kochi, A. (1994). Global tuberculosis incidence and mortality during 1990-2000. Bull. World Health Organ., 72, 213-220. 
5. Folgueira, L.; Delgado, R.; Palenque, E.; Noriega A.R. (1994). Polymerase chain reaction in the diagnosis of tuberculous meningitis in AIDS patients. Neurology, 44, 1336.

6. Girgis, N.I.; Sultan, Y.; Farid, Z.; Mansour, M.M.; Erian, M.W.; Hanna, L.S.; Mateczun, A.J. (1998). Tuberculosis meningitis, Abbassia Fever Hospital-Naval Medical Research Unit No. 3-Cairo, Egypt, from 1976 to 1996. Am. J. Trop. Med. Hyg., 58 (1), 28-34.

7. Harries, A.D. (1990). Tuberculosis and human immunodeficiency virus infection in developing countries. Lancet., 335 (8696), 387 390.

8. Hosoglu, S.; Ayaz, C.; Geyik, M.F.; Kokoglu, O.F.; Cerviz, A. (1998). Tuberculous meningitis in adults: an eleven-year review. Int. J. Tuber. Lung. Dis., 2 (7), 553-557.

9. Jatana, S.K.; Nair, M.N.; Lahiri, K.K.; Sarin, N.P. (2000). Polymerase chain reaction in diagnosis of tuberculosis in children. Ind. Pediatrics., 37,375 .

10. Kennedy, D.H.; Fallon, R.J. (1979). Tuberculous meningitis. JAMA. 241 (3), 264-268

11. Kox, L.F.; Kuijper, S.; Kolk, A.H. (1995). Early diagnosis of tuberculous meningitis by polymerase chain reaction. Neurology, 45 (12), 2228-2232.

12. Kulkarni, S.P.; Jaleel, M.A.; Kadival, G.V. (2005). Evaluation of an in-house-developed PCR for the diagnosis of tuberculous meningitis in Indian children. J. Med. Microbiol., 54, 369-373.

13. Lin, J.J.; Harn, H.J.; Hsu, Y.D.; Tsao, W.L.; Lee, H.S.; Lee, W.H. (1995). Rapid diagnosis of tuberculous meningitis by polymerase chain reaction assay of cerebrospinal fluid. J. Neurol., 242 (3), 147152.

14. Liu, P.Y.F.; Shi, Z.Y.; Lau, Y.J.; Hu, B.S. (1994) Rapid diagnosis of tuberculous meningitis: a simplified nested amplification protocol. Neurology, 44, 1161.

15. Melzer, M.; Brown, T.J.; Flood, J.; Lacey, S.; Bagg, L.R. (1999). False negative polymerase chain reaction on cerebrospinal fluid samples in tuberculous meningitis. J. Neura. Neurosurg. Psychiatry, 67,250

16. Miorner, H.; Sjorbring, U.; Nayak, P.; Chandramukhi, A. (1995). Diagnosis of tuberculous meningitis: a comparative analysis of 3 immunoassays, an immuno-complex assay and polymerase chain reaction. Tuber. Lung. Dis., 76: 38.

17. Nguyen, L.N.; Kox, L.F.; Lihn, D.P.; Sjoukje, K.; Kolk; A.H. (1996). The potential contribution of the polymerase chain reaction to the diagnosis of tuberculous meningitis. Arch. Neurol., 53 (8), 771-776.

18. Ogusku, M.M.; Sadahiro, A.; Hirata, M.H.; Hirata, D.C.R.; Zaitz, C.; Salem, J.I.. (2003). PCR in the diagnosis of cutaneous tuberculosis. Braz. J. Microbiol., 34 (2).

19. Pai, M.; Flores L.L.; Pai, N.; Hubbard, A.; Riley, L.W.; Colford, J.M.Jr. (2003). Diagnostic accuracy of nucleic acid amplification tests for tuberculous meningitis: a systematic review and metaanalysis. Lancet Infect. Dis., 3 (10): 633-643.

20. Raviglione, M.C.; Snider, D.E.; Kochi, A. (1995). Global epidemiology of tuberculosis. Morbidity and mortality of a world wide epidemic. JAMA, 273, 220-226.

21. Scarpellini, P.S.; Racca, P.; Cinque, F.; Delfanti, N.; Gianotli, M.R.; Terreni, L.V.; Lazzarin A. (1995). Nested polymerase chain reaction for the diagnosis and monitoring of response in AIDS patients with tuberculous meningitis. AIDS, 9 (8), 895-900.

22. Seth, P.; Ahuja, G.K.; Bhanu, N.V.; Behari, M.; Bhowmik, S.; Broor S.; Dar, L.; Chakraborty, M. (1996). Evaluation of polymerase chain reaction for rapid diagnosis of clinically suspected tuberculous meningitis. Tuber. Lung. Dis., 77, 353-357.

23. Shankar, P.; Manjunath, N.; Mohan, K.K. (1991). Rapid diagnosis of tuberculous meningitis by polymerase chain reaction. Lancet., 337, 5-7.

24. Shinnick, T.M.; Jones, J. (1994). Molecular approaches to the diagnosis of tuberculosis. In: Bloom BR, ed. Tuberculosis, Pathogenesis, Protection and Control. Washington DC: Am. Soc. Microbiol., 517-530.

25. Snider, D.E.Jr; Roper, W.L. (1992). The new tuberculosis. N. Engl. J. Med., 226, 703-705.

26. Tandon, P.N. (1978). Tuberculous meningitis. In P.J. Vinken and G.W. Bruyn (ed.), Handbook of clinical neurology. North Holland Publishing Co., Amsterdam, The Netherlands, 195-262.

27. Wood, M.; Anderson, M. (1998). Chronic meningitis. Neurological infections; major problems in Neurology, vol. 16. Philadelphia. WB Saunders, 169-248. 